\title{
Understanding and contextualizing teen dating violence
}

\author{
Compreendendo e contextualizando a violência nas relações de intimidade entre adolescentes \\ Comprensión y contextualización de la violencia en las relaciones de intimidad entre adolescentes
}

Maria das Graças Carvalho Ferriani ${ }^{1}$ Ana Beatriz Campeiz ${ }^{1}$ (D) José Eurípedes Martins ${ }^{1}$ (I) Ailton de Souza Aragão ${ }^{2}$ (1) Eliana Mendes de Souza Teixeira Roque ${ }^{3}$ (]) Diene Monique Carlos ${ }^{4}(\mathbb{D}$

1. Universidade de São Paulo. Ribeirão Preto, SP, Brasil.

2. Universidade Federal do Triângulo Mineiro. Uberaba, MG, Brasil.

3. Universidade de Ribeirão Preto. Ribeirão Preto, SP, Brasil.

4. Universidade Federal de São Carlos. São Carlos, SP, Brasil.

\section{Abstract}

Objective: To describe and analyze teen dating violence with adolescents of a public school in a city in the state of São Paulo. Method: Qualitative research, anchored by the Paradigm of Complexity. Data collection was carried out with 16 students of the $11^{\text {st }}$ year of high school, through focus groups and semi-structured interviews. Data analysis was based on the thematic modality. Results: There emerged three themes, which made it possible to understand that the myth of romantic love has still present in intimate relationships; as an aspect of these myths, jealousy is revealed as inherent in relationships, while time triggering teen dating violence at the same. Digital social networks have been throughout this process; the family and the school emerge as contexts that expose adolescents to vulnerability, including the experience of other violence manifestations. Conclusion and implications for practice: Multidimensional, retroactive and interdependent nature of the aspects related to teen dating violence were identified. Promotion of healthy dating relationships from the deconstruction of romantic love myths; safe use of virtual social networks by adolescents; actions to promote healthy parenting and articulation of health-school-family, with the empowerment of these spaces as factors to protect violence involving adolescents are necessary.

Keywords: Violence; Adolescent; School Health; Interpersonal Relations; Qualitative Research.

\section{Resumo}

Objetivo: Descrever e analisar a violência nas relações de intimidade entre adolescentes de uma escola pública de um município do interior do estado de São Paulo. Método: Pesquisa qualitativa, ancorada pelo Paradigma da Complexidade. Coleta de dados realizada junto a 16 estudantes do $2^{\circ}$ ano do ensino médio, por meio de grupos focais e entrevistas semiestruturadas. A análise de dados se deu pela modalidade temática. Resultados: Emergiram três temas, que possibilitaram compreender que o mito do amor romântico ainda se faz presente nas relações de intimidade; como aspecto desses mitos, o ciúme é desvelado como inerente às relações, sendo ao mesmo tempo disparador de violência nas relações de intimidade. As redes sociais digitais atravessam esse processo; a família e a escola emergem como contextos que vulnerabilizam os adolescentes, inclusive pela vivência de outras manifestações da violência. Conclusão e implicações para a prática: Identificou-se o caráter polidimensional, retroativo e interdependente dos aspectos relacionados ao fenômeno estudado. Traz a importância de ações no âmbito escolar e comunitário pelo enfermeiro, na desconstrução de mitos de amor romântico; uso seguro de redes sociais virtuais; promoção da parentalidade saudável e a articulação saúde-escola-família, com empoderamento desses espaços enquanto fatores de proteção a violências envolvendo adolescentes.

Palavras-chave: Violência; Adolescente; Relações interpessoais; Saúde escolar; Pesquisa qualitativa.

\section{RESUMEN}

Objetivo: Describir y analizar la violencia en las relaciones de intimidad entre adolescentes de una escuela pública de un municipio del interior del estado de São Paulo. Método: Investigación cualitativa, anclada por el Paradigma de la Complejidad. Recolección de datos realizada junto a 16 estudiantes del 2 ํoño de la enseñanza media, por medio de grupos focales y entrevistas semiestructuradas. El análisis de datos se dio por la modalidad temática. Resultados: Emergieron tres temas, que posibilitaron comprender que el mito del amor romántico aún se hace presente en las relaciones de intimidad; como aspecto de estos mitos, los celos se desvelan como inherentes a las relaciones, siendo al mismo tiempo disparador de la violencia. Las redes sociales digitales atravesan este proceso; la familia y la escuela emergen como contextos que vulnerabilizan a los adolescentes, incluso por la vivencia de otras manifestaciones de la violencia. Conclusión e implicaciones para la práctica: Se identificó el carácter polidimensional, retroactivo e interdependiente de los aspectos relacionados a la violencia en las relaciones de intimidad. La promoción de relaciones de intimidad sanas a partir de la deconstrucción de mitos del amor romántico; uso seguro de redes sociales virtuales por los adolescentes; las acciones de promoción de la parentalidad sana y la articulación salud-escuela-familia con empoderamiento de estos espacios como factores de protección a violencias involucrando adolescentes son necesarios.

Palabras clave: Violencia; Adolescente; Salud Escolar; Relaciones Interpersonales; Investigacion Cualitativa.
Submitted on $11 / 28 / 2018$

Accepted on 04/15/2019.

DOI: 10.1590/2177-9465-EAN-2018-0349
Corresponding author:

Diene Monique Carlos.

E-mail: diene_enf@hotmail.com 


\section{INTRODUCTION}

Unhealthy interpersonal relationships usually start early and can last a lifetime. In intimacy relations, due to the specificities they contain, the onset of violence is even more frequent and difficult to address. In the last years, studies have denoted an important relevance to teen dating violence..$^{1-4}$

Several terms have been used in the literature to conceptualize this violence among adolescents, and in this work we will consider the term teen dating violence. It is considered as physical, sexual, psychological or emotional violence in an intimacy relationship, including persecution. It is important to note that this violence may occur personally or virtually, as well as between casual or formal intimate partners. ${ }^{5}$

A survey conducted in the United States in 2011 showed that $23 \%$ of women and $14 \%$ of men who had experienced sexual violence, physical or intimate partner persecution; had the first experience of some type of violence in intimacy relations between 11 and 17 years of age. ${ }^{1}$ Another study found that approximately $10 \%$ of college students reported physical violence and $10 \%$ reported sexual violence by a dating partner in $2013 .{ }^{2}$

In Brazil, an important study carried out in ten capitals on violence in the affective-sexual relationships of 'hooking up' or dating, between $15-19$ year olds, revealed that $86.9 \%$ were already victims and $86.8 \%$ were already committed some type of violence during the relationship, whether physical, sexual or psychological. It was observed the naturalized and common presence of violence in at least one of its manifestations in the relations of intimacy among adolescents. ${ }^{3}$ The present study assumes that the myth of romantic love - understood as an eternal fusion and complementarity between two people in love and associated with the ideal of happiness ${ }^{3}$ - can present itself as a trigger for situations of violence. Expressed in other ways, it may be present in contemporary intimacy relations. Violence in intimate relationships brings consequences to the physical and mental health of adolescents in short and long term. Crosssectional studies have shown that adolescents who are victims of this violence are at increased risk for symptoms related to depression and anxiety; involvement in unhealthy behavior such as tobacco, alcohol, and other psychoactive substances; onset of antisocial behavior and suicidal thoughts. ${ }^{4-6}$

Adolescence is a "key period" of human development that enables the implementation of actions that will promote a healthy adult life..$^{7-8}$ It should be understood as a plural adolescence, and public actions and policies should be based on this diversity. ${ }^{9}$

Thus, literature is still incipient in the discussion of teen dating violence, especially in qualitative studies that consider the contexts where they are inserted. Considering these aspects, the guiding question of this study is: what is the meaning attributed to teen dating violence in secondary schools? According to the above, it is presented as the objective of this study to describe and analyze violence in intimacy relations among adolescents of a public high school in a countryside city in the state of São Paulo.

\section{METHOD}

This study has a qualitative research, strategic social type and anchored in the Paradigm of Complexity. This considers the look at phenomena in an articulated and polidimensional way; seeks to encompass aspects that are inseparable in the composition of a given phenomenon. ${ }^{10}$ Paradigm of Complexity is opportune to base this research, allowing a look at the interactions and contexts with a transdisciplinary approach, seeking to encompass reality. ${ }^{10}$ The notions of contextualization and understanding directed the data analysis. ${ }^{10}$ Contextualizing is the transdisciplinary look at a given phenomenon, in order to understand it, considering its multidimensionality. Comprehension can be understood as the meaning understanding of an object or event considering its relations with other objects or events. ${ }^{10}$

The study was carried out in a district of a countryside city of the state of São Paulo, with approximately 583,542 inhabitants. The district has an estimated population of 141,998 inhabitants; is located in the West peripheral region, and of high social vulnerability; and shows a high rate of urban, domestic and school violence. The public health network has 18 units, being a Basic District Unit, eight Basic Health Units and nine Family Health Units. It has nine municipal schools and eight state schools, totaling 4051 students. The research was conducted in one of the state schools that offers elementary and middle school in the morning, afternoon and evening.

Participants in the research were high school seniors in the morning, regularly enrolled and attending classes. Students who were removed from school for health leave or other reasons were excluded. The choice for the $2^{\text {nd }}$ year was due to the moment of academic transition that these adolescents lived, corroborating the literature's indications, since they may experience conflicts in this process. ${ }^{11}$ In the selected school, there were three classes of the $2^{\text {nd }}$ year, and management chose to start the activity in a class where there were situations of violence in intimacy relations. Of 37 students enrolled in this class, two were on health leave at the time of collection; and three were not attending classes for unknown reasons. At first, the others accepted to participate in the research, but only 16 signed the Free and Informed Assent Term (FIAT), and the Free and Informed Consent Term (FICT) by the parent and/or guardian.

Focus groups and semi-structured interviews were used to collect data. As a complement, the field diary was used during the entire collection process to record the input information in the field; approximation of participants; details of collection techniques; and progress of the research. A focus group was held in March 2018, with 16 students, in a room reserved for groups in the school, with good acoustics and luminosity. The group was held in a schedule that did not hinder academic activities; as indicated, was attended by a moderator and two observers. In the present research, phrases of situations experienced in intimate relationships among adolescents were used, which refer to situations of teen dating violence and romantic love 
myths, such as "Love supports everything"; "He/she is the half of my orange"; "Woman's place is in the kitchen". Later, these lines were problematized with the following guiding questions: how are intimate relationships among adolescents? What is the purpose of these relations? Which behaviors are positive and which are harmful in these relationships?

As a way to complement the data, seven semi-structured interviews were conducted in April 2018 with adolescents participating in the focus group who were invited to be part of these interviews; these were carried out in the same room as the group occurred. The script started with the following open and guiding questions: what do you mean by intimate relationships? How do you think violence happens in these relationships? Code saturation was chosen to be studied in this study. This is used to identify aspects relevant to the response of a study question and to form a robust description of subjects. ${ }^{12}$ As pointed out below, some elements for the understanding and contextualization of teen dating violence, which began to be repeated and deepened in the speeches, guided this saturation: perceptions about established intimacy relations; how the occurrence of violence in these relations unfolds; the relevance of social networks; the impact of violence that occurs in other spaces in the life of adolescents and, in particular, in a context more vulnerable to violence in intimate relationships. Saturation occurred with the focus group speeches and in the seventh interview.

The focus group and the interviews were recorded using a voice recording application for mobile handsets, and manually transcribed. The focus group lasted 1 hour, 12 minutes and 41 seconds; the longest interview had 60 minutes, while the shorter interview lasted 45 minutes. To guarantee the anonymity of participants, the speeches of the focus group were codified by the letters FG, and the letter $\mathrm{M}$ for male adolescents and $\mathrm{F}$ for female. For the interviews, the letter I was used, maintaining the same codification for gender differentiation; were numbered from the sequences in which they were performed. Field diary's data were used, essentially, to describe the data collection.

The data were analyzed through the Complexity Pradigm and guided by two main notions: contextualization and understanding. ${ }^{10}$ The thematic analysis technique directed this analysis through the following steps: ${ }^{13}$ familiarization with data: after transcription of the interviews and groups, readings and exhaustive re-readings of the data set were performed; coding: we sought to reference and encode the relevant information according to the research questions through codes that captured the semantic and conceptual reading of the data; codes were grouped with the relevant data extracted from the information set; search for themes: a theme is consistent and significant pattern in the data relevant to the response of the research question; the codes of the previous phase were grouped in these subjects; review of themes: the themes were checked whether they worked according to the extracted data codes and their relation to the general set of data; definition and naming of the themes: the detailed writing of the analysis of each theme was carried out, identifying the essence of each one; final writing: a comprehensive element of the thematic analysis, which involves the joint reading of the analytic narrative, as well as its contextualization with the relevant literature of the area, legal devices and articulation with theoretical concepts. In order to guarantee greater validity and reliability of the data, the following strategies were carried out: member-checking: return of the data to participants for "checking" the coherence of the content; peer analysis: the construction of reference charts and categories were given by two study researchers, and validated by a third party when necessary; use of the field diary, ensuring greater transparency of the entire research process.

The steps of coding and definition of themes are presented in Chart 1.

The research met the ethical aspects involving human beings, being approved by the Ethics Committee of the Escola de Enfermagem Ribeirão Preto of the Universidade de São Paulo (Opinion 2,439,567/2017), and authorized by the school research setting. It is reiterated that the information was collected only after the signing of the FICT by the guardians of students and the FIAT by students.

\section{RESULTS}

Among the 16 participating students, nine were female and seven males. Of these, seven adolescents participated in the individual interviews, being three females and four males. Adolescents were between 16 and 17 years old; four lived with their father and mother; six lived only with their mother; one lived with his father and his paternal grandmother; one lived with his father; and four lived with grandparents and/or uncles. All families had less than one minimum wage and lived in an area of social vulnerability.

Two adolescents reported not having experienced intimate relationships; one teenager reported having suffered violence in these relationships.

Following the thematic analysis, three themes emerged as follows.

\section{$1^{\text {st }}$ theme- "Prince and Princess ": understanding intimacy relationships among adolescents}

In this theme, there was evidence of the ideal of romantic love - the existence of a relationship that "transforms" the adolescent into "prince and princess":

... when you love a person you like, there is going to be Prince Charming, the princess. He'll be your prince, she'll be your princess.... (FGF).

... the feeling turns the person into a princess or prince, not wanting to mix fiction with reality, but it is the best term to put into it (FGM). 
Chart 1. Coding and definition of themes. Prepared by the authors. Ribeirão Preto, 2018

\begin{tabular}{|lll|}
\hline \multicolumn{1}{|c|}{ Initial codes } & \multicolumn{1}{c|}{ Intermediate codes } & \multicolumn{1}{c|}{ Final themes } \\
\hline Dating is a serious thing & Prince and Princess & Prince and Princess \\
Having a prince or princess & Passion $x$ Love & \\
Feelings transform & Future & \\
Perfect person & & \\
Having a future & & \\
Getting married and having kids & & \\
Passion is faster & & \\
It can be just sex & Jealousy and violence & \\
Jealousy & Social media & At home and School did nothing \\
When violence happens & \\
I have problems with Facebook & Parents separation & \\
New family structures & Domestic violence \\
Parents separation & School violence & \\
Mother did not do anything & & \\
School does nothing & & \\
Bullying & & \\
\hline
\end{tabular}

It is noticed in the speeches that adolescents maintain an idealized feeling, that turns the other always in a better person; use the metaphor "prince" and "princess" to mean romantic love. In this respect, semantics also become important, as it indicates in some way the way teenagers perceive their relationships - in an almost magical way, the transformation of the other into a mixture of reality and fiction.

Still in this aspect, adolescents differentiate, even if shyly and in few words, the different relationships existing from two aspects. The first relates to the intensity of this relationship by differentiating 'passion' and 'love'; passion is associated with shorter relationships, occasional and less stable. Some terms are associated with these experiences, such as to fuck:

The person goes faster with passion, because passion can be a momentary thing... (FGF).

You met the person, she looked beautiful ... ah, I have to fuck this person ... sometimes in one night (FGM).

The second aspect, as approached in this last speech, shows the ultimate goal of the relationship, being more important to date because it is associated with the ideal of marriage and love:

We started to like each other three years ago, and dating is to get married, in my view dating is to get married... (FGF).
Love is more tranquil ... we talk, we complete each other and also hug, kiss (FGM).

There is an important gender difference - adolescents bring more colloquial and aggressive vocabularies, such as fuck, while adolescents allude to dating, marriage, and a stable relationship. As reported above, the myth of romantic love is associated with the ideal of eternal marriage, leading some adolescents to live for the other, losing their individualities:

... create a life, be able to have someone who can relate and from the moment you relate to someone ... you not only live your life, you have to live her life too, you have to adapt with her (IF1).

\section{$2^{\text {nd }}$ theme - "From jealousy to violence": understanding teen dating violence}

As they entered the violent aspects of intimacy relations, adolescents brought, in a resounding way, the issue of jealousy as a trigger for violence in these relationships:

Of violence among adolescents, the girl was 14 years old and the boy was 17 years old. With so much jealousy, he even killed her (IF1).

It's a mix of all this, jealousy, violence. The person is dead with jealousy and will not call if it was raining, it 
was snowing, if you got stuck on the Titanic, you had to be there. Fuck it, there's nothing left. You are hers [our writing] (IM3).

In the discussions, jealousy was associated with the feeling of ownership, as evidenced in the speech above and below:

[...] my boyfriend is very possessive, I cannot talk to my cousins because he does not like it (FGF).

In a dialogical way, the discussion of the naturalized presence of jealousy in the relationship also emerged as part of any intimacy relationship:

Dating can go through some kind of fight like this, if you talk to someone else you're cheating on me, I get jealous... (IM4).

... feeling jealous of her shorts, talking to someone I do not know... (IM3).

It was also pointed out by adolescents that there is 'natural' jealousy in relation to love, and one that can be 'pathological'. In this way, there is a quantification of this jealousy, however without concrete definition of what would be the borderline of the 'natural' and 'pathological':

... you may be jealous, not much, because that is love (IF2).

... jealousy if you like the person, you feel jealous (IF1).

Jealousy was also related to control. In this sense, it was evident the immersion in the digital age by adolescents and our society. This phenomenon (jealousy-control) is essentially perceived by the use of social networks, especially by the sharing of 'electronic passwords':

... he does not like me talking on the phone [Whatsapp] ... he wants to know my password and I do not like it (FGF).

One can perceive the experience of intimacy relations in social networks, in a public way; In this sense, violence in these relationships among adolescents also capillizes in this environment, in a non-linear and retroactive way:

I have problems with Facebook, because I think a lot of girls see that the guy is married and shameless, go and send a photo and say: hi baby... (IF2).

I find it weird your boyfriend posting things showing boobs, butt, shameless phrases (FGF).
Adolescents also reinforced some aspects of violence in intimacy relationships that served as warning signs. The issue of feeling disrespected, manipulated, and afraid is relevant:

... violence does not have to be being slapped, violence can be being disrespectful, it can be being manipulated in a way to do what it does not want as a sexual relationship (IF1).

... if you're in the relationship, you're feeling scared that something is not right (FGF).

\section{$3^{\text {rd }}$ theme - "At home" and "school did nothing": contextualizing teen dating violence}

As mentioned in the characterization of participants, the majority of the families of adolescents are of separated parents who experienced the violence due mainly to the use of psychoactive substances and unemployment; the emergence of new family configurations became evident. It was possible to identify, in the dialogues of adolescents, the experience of situations of violence among their parents, especially of the man against the woman:

I remember the fights that happened and my mother said, "let's go to grandma's [house]" so as not to see the fights ... he would arrive Saturday, he would drink, go home and beat the gate at dawn, break things and my mother said, "go away"... (IM2).

Social networks also emerged as relevant aspects for conflicts between parents of adolescents, denoting the central role of digital media in society:

There at home is hard, economic problem, my mother alone with three children ... my mother's quarrel with my normal father, it was because of my mother who started all this ... my father took her cell phone and there it started the fights ... And because she was on her cell phone, he suspected a friend of hers... (IM3).

Another point that is evident in the speeches of these adolescents is the lack of dialogue and care within the family. Some seek and find these affective behaviors with the boyfriend/ girlfriend:

This case [of intimacy relations violence] had a problem with family ... the mother was a drug user, she did not care, she went into the life of the crime, she became angry, and she used drugs and turned all that... (IF1). 
A little distant from me, my family, my father, does not pay attention to me, my mother is that person who is not even there... (IF1).

My boyfriend who talks to me, I come from school he who sees my notebook, asks how my day was (IF3).

Adolescents bring difficulties experienced in schools after separation of parents and experiences in new family settings, and report some situations of bullying:

I was not like that, I was an extroverted person and I think this has to do with separation from my father ... not wanting to blame only this, then I went to live with my grandmother has the adaptation... (IM2).

I started to face a lot of problems like "ah who you hooked up with", and I suffered bullying and then with these problems I kind of appear, then anger was getting into me, I got nervous, getting closed and deleted... (IM3).

Adolescents still expose the absence of social support for help in handling these situations experienced:

I think like no one helps me to give advice so I get scared and afraid to try to do it like that ... then stay inside me, got it... (IM2).

The experience (or not) of intimacy relations permeates school; in some situations, one also perceives bullying arising from these issues:

There is enough girl that sometimes wants to hook up with me, dating, but I said I do not want to ... I even go through bullying because she says that she is beautiful and everyone wants to date her ... annoys, fills her head with so much they talk about it, like but I usually do not even call but I get sad (IM2).

Although this violence permeates school, it is evidenced in the speeches the still difficulty of intervention of school to face these situations:

Five boys against a girl here at school, and school did nothing (IF1).

\section{DISCUSSION}

Considering the Paradigm of Complexity, ${ }^{10}$ which seeks to understand the frames of relations that make up a given phenomenon (what is "woven together"), as well as the notions of understanding and contextualization that support this analysis, the following explanatory model was elaborated (Figure 1) for teen dating violence.

Figure 1. Explanatory model of understanding and contextualization of violence in intimacy relationships among adolescents.

Prepared by the authors. Ribeirão Preto, 2018

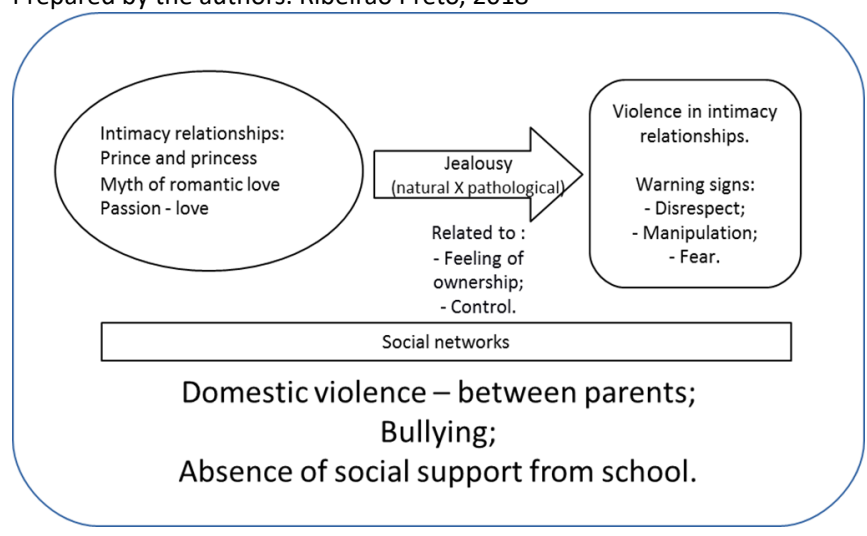

Contemporary intimacy relationships among adolescents remain demarcated by myths of romantic love - if on the one hand, the relationships associated with passion are "fortuitous", commonplace and characterized by hooking up/fucking, the relationships associated with love are characterized by stability, person unique/ideal and eternalized. In this context, jealousy is considered inherent to relationships, except when it can be 'pathological', marked by the feeling of ownership and control. Jealousy can lead to situations of violence, with adolescents highlighting aspects of this phenomenon - fear, manipulation and disrespect. These relationships are crossed by digital media as if there is a "parallel world" where these adolescents also experience their relationships. There is a feedback of the characteristics listed and lived by adolescents in their relations of intimacy to the occurrence of violence in these relationships, and cannot be analyzed separately or in relation to cause and effect. In addition to this aspect, it is perceived that the whole (violence in intimate relations) is in the parts, as well as the parts are expressed in the whole. ${ }^{10}$

As woven interdependent present in this scope, there are immediate contexts of adolescent life, namely school and family. The latter emerges with important factors that make these adolescents vulnerable to establishing unhealthy relationships. Gender violence among parents; the lack of dialogue and care in the family is one of the factors. At school, adolescents experience violence among partners, without a proactive and effective confrontation of this institution. It denotes the retroaction of these elements, principle of complexity that considers non-linearity, in which not only cause acts on the effect, but the effect retroacts on the cause. Thus, these elements are both producers and products of the phenomenon of teen dating violence.$^{10} \mathrm{It}$ should 
be clarified that such elements have been divided into categories for a better description, but the inseparable nature of them is reiterated. Such aspects can subsidize nursing care actions, denoting the expanded and articulated view of the adolescent's vulnerabilities. $^{9}$

The myth of romantic love is referred to and discussed by several authors, being pointed as myth for presenting itself as a set of socially shared and little flexible beliefs. ${ }^{14}$ Thus, some aspects are found in the adolescent's speech - the existence of an ideal partner; omnipotence; the wedding; the relationship eternalized, exclusively because there is the ideal person. ${ }^{14} \mathrm{It}$ links strongly to the ideal of happiness and intense fusion with the other. ${ }^{3}$ These aspects are referred to by the study participants, as in the words "living the life of another." Jealousy also emerges as an element of myth, to be better discussed later. In this sense, despite the new forms of relationship, these are still permeated by these myths.

Adolescents presented ways of relating reported in other studies of the area. ${ }^{3,15}$ However, in this study, they strongly related 'to fuck/to hook up' to passion, and 'dating' to love. In this sense, they reinforce the myths of idealized love. It is emphasized that, despite the conceptualizations, the experiences surpass these categorizations.

As outlined above, jealousy was the main determinant for the occurrence of violence in intimate relationships among adolescents, being considered natural and belonging to any of intimacy relationships by participants and linked to the ideal of romantic love. Jealousy leads to a negative and complex emotional experience; occurs in a perception of loss or deterioration of a significant relationship by the appearance of a third person, and this threat may be real or imaginary. ${ }^{15} \mathrm{It}$ is a form of power and domination converted into a control strategy used by the perpetrators. This control takes place through the behaviors of the other and of the relations of the partner, ${ }^{15}$ being, therefore more than an implicit violence. Thus, the findings of this study strongly corroborate the literature regarding the relationship between jealousy and possession/control. Another Brazilian study ${ }^{3}$ found such findings, especially as a trigger for manifestations of all forms of violence. Therefore, the myths supported by romantic love as factors of high vulnerability to teen dating violence.${ }^{15} \mathrm{Control}$, totally directed to the response-consequence of jealousy by participants of this study, has been pointed out as one of the main manifestations of this violence among adolescents, especially in the digital environment. ${ }^{16-17}$

Intimacy relationships among adolescents were permeated by experiences in virtual social networks, especially on Facebook. As pointed out earlier, it is understood that this environment is understood as natural to adolescents, considered digital natives, and a contemporary "identity contour". ${ }^{17}$ This virtual environment crosses both the intimacy relations and the violence that emerge in them. ${ }^{16}$ "Sharing of passwords" became the greatest proof of love, with no differences by gender. A qualitative study with university students corroborated these findings, revealing that despite criticism of the publicity of private life, they recognize that it is a requirement already incorporated into the current culture. ${ }^{17}$

Digital teen dating violence has been explored by international scientific literature in recent years, including behaviors of using digital media to monitor, control, threaten, injure, coerce, or coerce an intimate partner. ${ }^{18} \mathrm{~A}$ study developed in Belgium with students from 16 to 22 years who were in intimate relationships, identified that involvement in risky online behaviors; the longer duration of the relationship; sending messages with sexual content to the partner; and the greater number of social networks used were significantly related to the victimization of violence in digital intimacy mediated by control. ${ }^{19}$

A qualitative study with adolescents aged 12 to 18 years in the UK sought to explore the role of the use of technologies in their intimacy relationships. ${ }^{20}$ These technologies can have a positive impact on the development and maintenance of relationships, but can provide a new pathway for unhealthy behaviors. They may also be perceived as less harmful than violence "in person". ${ }^{20}$ Another US study with university students indicates that violence in intimate relationships lived in digital media is part of other violence. ${ }^{21}$ In this sense, it alerts to the importance of describing these violence in the social contexts where they are experienced, in order to perceive where online experiences function as a "portent" of future violence. ${ }^{21}$ In this context, nurses, because of the privileged position they occupy in the teams and services, emerges as an essential and primordial figure for approaching adolescents and their families, and can contribute to the construction of actions for the safe and healthy use of the Internet, especially through intersectoral actions at school. ${ }^{22}$

The perceived disrespect and manipulation/control arising from the situation of violence experienced, as well as the fear felt by the actions of the partner, were the highlighted signals for seeking help and support. Adolescents who experience these feelings can have consequences for physical and mental health. ${ }^{4,6}$ As already indicated, the identification of this violence is hampered by personal and social factors. This fact is aggravated in adolescence, when people have greater difficulty in perceiving and talking about these situations of violence. ${ }^{5}$ Nursing needs to be sensitive, capable and act in a coordinated way to other services and longitudinal in caring for children and adolescents to host and cope with the situations of violence to which this population is exposed. ${ }^{23,24}$

In this context of seeking help and support, the family and school are the places of greatest coexistence and could have the best strategies to confront and/or prevent teenage violence. Literature review highlighted the risk and protective factors for the perpetration of violence in intimate relationships among adolescents. Among the social protection factors, having a positive relationship with the mother and the sense of belonging to the school were identified. ${ }^{2}$ Despite the potency of these contexts, they still do not effectively assume their protective role, as reported by study participants. These data corroborate a 
study that analyzed the search for services and support network of adolescents in the city of Porto Alegre, Brazil, to confront violence in intimacy relations. ${ }^{25}$ Among the study participants, only $5 \%$ sought help in situations of violence; friends were the most wanted, followed by relatives. ${ }^{25}$

Experiences of violence in the family, whether witnessing violence among parents or suffering domestic violence, may have an impact on the development of adolescents, especially in the construction of their relationships with peers. Conflicts in relationships among parents can influence beliefs and behaviors about what is acceptable in their own relationships. ${ }^{26}$ Violence in childhood, even indirect (witnessing conflicts among parents) and economic vulnerability are presented as risk factors for violence in relations of intimacy. ${ }^{26}$ The study, mentioned above, carried out in the city of Porto Alegre, confirms that adolescents want an open dialogue with their parents. However, there are gaps between what is idealized and what happens in reality. ${ }^{25}$

As already mentioned, school did not promote protection in situations of these violence; dialogically, has emerged as a locus for the occurrence of violence, especially bullying. The literature has turned to the discussion of this issue given its magnitude as a health problem in the life of adolescents. ${ }^{27}$ The experience of bullying at school should be emphasized, motivated by situations of intimacy relations or family characteristics, and it is perceived that the violence occurs concomitantly in the life of many adolescents. The literature has pointed out that many forms of violence are interconnected and generally share the same roots, and may occur together in families and communities, and at the same time or throughout life cycles. ${ }^{26}$ Understanding and implementing approaches that prevent risk factors and promote protection that are common to various types and manifestations of violence can help practitioners use limited resources to prevent violence and save lives more efficiently. ${ }^{26}$ Nursing and health should guide their agenda in the recognition of adolescent care as emancipatory, comprehensive, contextual and dialogic practice. Therefore, it is suggested the search for references that respect the non-universality of the adolescent being and the several aspects that vulnerabilize or protect them, in an interdisciplinary and inter-sectoral way. ${ }^{9}$

\section{CONCLUSIONS AND IMPLICATIONS FOR PRACTICE}

The findings of this study revealed the multidimensional, retroactive and interdependent nature of the aspects related to violence in intimacy relations among adolescents. These relationships are permeated by myths of romantic love; jealousy is seen as the main trigger of violence and associated with control. The virtual context crosses relationships and violence; fear, manipulation and disrespect are listed as warning signs of violence in intimate relationships. Violence in the family and school retroaction in the production of this violence.
From these results, implications for the practice of nursing and health are pointed out, namely: the construction of strategies to promote healthy intimacy relationships from the deconstruction of romantic love myths; actions that promote the safe use of virtual social networks by adolescents, such as workshops and dynamics for adolescents and families; actions to promote healthy parenting for families and caregivers of adolescents; health-school-family articulation, with empowerment of these spaces as factors of protection against violence involving adolescents.

The limitations of the study were related to the choice of participants. It is a specific context and a group chosen for having already experienced violence in intimate relationships; differentiation by gender could also have been considered. New studies with younger adolescents, parents and/or caregivers and education professionals, as well as evaluation of the implementation of programs aimed at prevention of violence among adolescents, are recommended.

\section{FINANCIAL SUPPORT}

This study was financed by Research Support Foundation of São Paulo State (Fundação de Amparo à Pesquisa do Estado de São Paulo), Regular Research Project, Process 2015/24069-5.

\section{REFERENCES}

1. Black MC, Basile KC, Breiding MJ, Smith SG, Walters ML, Merrick MT, Chen J, Stevens MR. The National Intimate Partner and Sexual Violence Survey (NISVS): 2010 Summary Report. Atlanta (GA): National Center for Injury Prevention and Control, Centers for Disease Control and Prevention; 2011.

2. Vagi KJ, Olsen EOM, Basile KC, Vivolo-Kantor AM. Teen dating violence (physical and sexual) among US high school students: Findings from the 2013 National Youth Risk Behavior Survey. JAMA Pediatr [Internet]. 2015 may; [cited 2018 nov 12]; 169(5):474-482. Available from: https:// www.ncbi.nlm.nih.gov/pmc/articles/pmid/25730143/ doi:10.1001/ jamapediatrics.2014.3577

3. Minayo MCS, Assis SG, Njaine K, organizadores. Amor e violência: um paradoxo das relações de namoro e do 'ficar' entre jovens brasileiros [Internet]. Rio de Janeiro: Editora FIOCRUZ;2011. Available from: http:// books.scielo.org/id/4c6bv Doi:10.7476/9788575413852

4. Foshee VA, Reyes HL, Gottfredson NC, Chang LY, Ennett ST. A Longitudinal Examination of Psychological, Behavioral, Academic, and Relationship Consequences of Dating Abuse Victimization Among a Primarily Rural Sample of Adolescents. J Adolesc Health [Internet]. $2013 \mathrm{dec}$; [cited 2018 oct 17]; 53(6):723-729. Available from: https://doi.org/10.1016/j.jadohealth.2013.06.016 Doi: 10.1016/j. jadohealth.2013.06.016

5. Centers for Disease Control and Prevention - CDC. National Centre for Injury Prevention and Control. Division of Violence Prevention. Understanding Teen Dating Violence. Fact Sheet 2016. Available from: http://www.cdc.gov/violenceprevention/pdf/teen-dating-violencefactsheet-a.pdf

6. Exner-Cortens D, Eckenrode J, Rothman E. Longitudinal associations between teen dating violence victimization and adverse health outcomes. Pediatrics [Internet]. 2013 jan; [cited 2018 oct 17]; 71:71-78. Available from: https://www.ncbi.nlm.nih.gov/pubmed/23230075 doi: 10.1542/peds.2012-1029 
7. Malta DC, Mascarenhas MDM, Dias AR, Prado RR, Lima CM, Silva MMA, et al. Situations of violence experienced by students in the state capitals and the Federal District: results from the National Adolescent School-based Health Survey (PeNSE 2012). Rev Bras Epidemiol [Internet]. 2014; [cited 2017 feb 08]; 17(Suppl 1):158-71. Available from: http://www.scielo.br/pdf/rbepid/v17s1/1415-790X-rbepid-17-s1-00158. pdf Doi: 10.1590/1809-4503201400050013

8. Kothari A, Sibbald SL, Wathen CN. Evaluation of partnerships in a transnational family violence prevention network using an integrated knowledge translation and exchange model: a mixed methods study. Health Res Policy Syst [Internet]. 2014 may; [cited 2015 nov 17] 12:25. Available from: http://health-policy-systems.biomedcentral.com/ articles/10.1186/1478-4505-12-25 Doi: 10.1186/1478-4505-12-25.

9. Silva MAI, Mello FCM, Mello DF, Ferriani MGC, Sampaio JMC, Oliveira WA. Vulnerability in adolescent health: contemporary issues. Ciênc Saúde Coletiva [Internet]. 2014 feb; [cited 2019 feb 24]; 19(2):619627. Available from: http://www.scielo.br/scielo.php?script=sci_ arttext\&pid=S1413-81232014000200619\&Ing=en Doi: 10.1590/141381232014192.22312012

10. Morin E. Ciência com consciência. $8^{\mathrm{a}}$ ed. Rio de Janeiro: Bertrand Brasil; 2005.

11. Carlos DM, Campeiz AB, Silva JL, Fernandes MID, Leitão MNC, Silva MAl, et al. Intervenções na escola para prevenção da violência nas relações de intimidade entre adolescentes: revisão integrativa da literatura. Rev Enf Ref [Internet]. 2017 set; [cited 2018 nov 03]; serIV(14):133-146. Avalilable from: http://www.scielo.mec.pt/scielo. php?script=sci_arttext\&pid=S0874-02832017000300014\&Ing=pt Doi: 10.12707/RIV17030

12. Hennink MM, Kaiser BK, Marconi VC. Code Saturation Versus Meaning Saturation: How Many Interviews Are Enough?. Qual Health Res [Internet]. 2016 sep; [cited 2018 oct 17]; 27(4):591-608. Available from: https://journals.sagepub.com/doi/full/10.1177/1049732316665344? url_ver=Z39.88-2003\&rfr_id=ori\%3Arid\%3Acrossref.org\&rfr_dat=cr_ pub\%3Dpubmed Doi: 10.1177/1049732316665344

13. Clarke V, Braun V. Teaching thematic analysis: Overcoming challenges and developing strategies for effective learning. The Psychologist [Internet]. $2013 \mathrm{sep}$; [cited 2016 oct 20]; 26(2):120-123. Available from: http://eprints.uwe.ac.uk/21155

14. Yela C. La otra cara del amor: mitos, paradojas y problemas. Encuentros Psicol Soc. 2003;1(2):263-267.

15. Unidade de Investigação em Ciências da Saúde - Enfermagem (UICISA-E). Prevenir a violência no namoro: $n$ (amor)o (im)perfeito fazer diferente para fazer a diferença. Série monográfica - Educação e investigação em saúde. Coimbra: Unidade de Investigação em Ciências da Saúde - Enfermagem [Internet]. 2013; [access 2017 nov 10]. Available from: https://web.esenfc.pt/v02/pa/conteudos/downloadArtigo. php?id_ficheiro $=555 \&$ codigo $=$

16. Flach RMD, Deslandes SF. Abuso digital nos relacionamentos afetivo-sexuais: uma análise bibliográfica. Cad Saúde Pública [Internet]. 2017; [cited 2018 nov 11]; 33(7):e00138516. Available from: http://www.scielo.br/scielo.php?script=sci_arttext\&pid=S0102$311 \times 2017000702001 \&$ Ing=en Doi: $10.15090 / 0102-311 \times 00138516$

17. Moreira JO, Lima, NL, Stengel M, Pena BF, Salomão CS. A exposição do amor na internet: público ou íntimo? Arq Bras Psicol [Internet]. 2017; [cited 2018 nov 03]; 69(1):5-18. Available from: http://www.redalyc.org/ pdf/2290/229053872002.pdf
18. Reed LA, Tolman RM, Ward LM. Gender matters: Experiences and consequences of digital dating abuse victimization in adolescent dating relationships. J Adolesc. 2017 aug;59:79-89. doi: 10.1016/j. adolescence.2017.05.015

19. Ouytsel JV, Ponnet K, Walrave M. Cyber Dating Abuse Victimization Among Secondary School Students From a Lifestyle-Routine Activities Theory Perspective. J Interpers Violence [Internet]. 2016 feb; [cited 2018 nov 11]; 33(17):2767-2776. Available from: https:// journals.sagepub.com/doi/full/10.1177/0886260516629390 Doi: 10.1177/0886260516629390

20. Stonard KE, Bowen E, Walker K, Price SA. "They'll Always Find a Way to Get to You": Technology Use in Adolescent Romantic Relationships and Its Role in Dating Violence and Abuse. J Interpers Violence [Internet] 2015 jun; [cited 2018 nov 11]; 32(14):2083-2117. Available from: https://journals.sagepub.com/doi/10.1177/0886260515590787 Doi: 10.1177/0886260515590787

21. Marganski A, Melander L. Intimate Partner Violence Victimization in the Cyber and Real World: Examining the Extent of Cyber Aggression Experiences and Its Association With In-Person Dating Violence. J Interpers Violence [Internet]. 2015 nov; [cited 2018 nov 11]; 33(7): 1071 1095. Available from: $h$ ttps://journals.sagepub.com/doi/full/10.1177/088 6260515614283?url_ver=Z39.88-2003\&rfr_id=ori\%3Arid\%3Acrossref. org\&rfr_dat=cr_pub\%3Dpubmed Doi: 10.1177/0886260515614283

22. Beserra GL, Ponte BAL, Silva RP, Beserra EP, Sousa LB, Gubert FA Atividade de vida "comunicar" e uso de redes sociais sob a perspectiva de adolescentes. Cogitare Enferm [Internet]. 2016 jan; [cited 2018 nov 11];21(1):01-09. Available from: https://revistas.ufpr.br/cogitare/article/ view/41677/27247 Doi: 10.5380/ce.v21i4.41677

23. Leite JT, Beserra MA, Scatena L, Silva LMP, Ferriani MGC. Coping with domestic violence against children and adolescents from the perspective of primary care nurses. Rev Gaúcha Enferm [Internet]. 2016; [cited 2019 feb 24]; 37(2):e55796. Available from: http://www.scielo.br/scielo.php?script=sci_arttext\&pid=S1983-14472016000200415\&Ing=en Doi:10.1590/1983-1447.2016.02.55796

24. Ferriani MGC, Carlos DM, Oliveira AJ, Esteves MR, Martins J. Institutional links to cope with school violence: an exploratory study. Esc Anna Nery [Internet]. 2017; [cited 2019 feb 24]; 21(4):e20160347. Available from: http://www.scielo.br/scielo.php?script=sci arttext\&pid=S141481452017000400202\&Ing=en Doi:10.1590/2177-9465-ean-2016-0347

25. Soares JSF, Lopes MJM, Njaine K. Violência nos relacionamentos afetivo-sexuais entre adolescentes de Porto Alegre, Rio Grande do Sul, Brasil: busca de ajuda e rede de apoio. Cad Saúde Pública [Internet]. 2013 jun; [cited 2018 nov 12]; 29(6):1121. 1130. Available from: http://www.scielo.br/scielo.php?script=sci arttext\&pid=S0102-311X2013000600009\&Ing=en Doi: 10.1590/ S0102-311X2013000600009

26. Wilkins N, Myers L, KuehI T, Bauman A, Hertz M. Connecting the Dots: State Health Department Approaches to Addressing Shared Risk and Protective Factors Across Multiple Forms of Violence. J Public Health Manag Pract [Internet]. 2018 jan/feb; [cited 2018 nov 12]; 24(Suppl 1):S32-S41. Available from: https://www.ncbi.nlm.nih.gov/pmc/articles/ PMC5815838/ Doi: doi: 10.1097/PHH.0000000000000669

27. Oliveira WA, Silva JL, Yoshinaga ACM, Silva MAI. Interfaces entre família e bullying escolar: uma revisão sistemática. Psico-USF [Internet]. 2015; [cited 2018 nov 12]; 20(1):121-132. Available from: https://dx.doi.org/10.1590/1413-82712015200111 Doi: 10.1590/141382712015200111 